Prepared in collaboration with the U.S. Fish and Wildlife Service

\title{
Model of Whooping Crane Energetics as Foundation for Development of a Method to Assess Potential Take during Migration
}

Open-File Report 2012-1156 



\section{Model of Whooping Crane Energetics as Foundation for Development of a Method to Assess Potential Take during Migration}

By Aaron T. Pearse and Sarena M. Selbo

Prepared in collaboration with the U.S. Fish and Wildlife Service

Open-File Report 2012-1156 


\title{
U.S. Department of the Interior \\ KEN SALAZAR, Secretary \\ U.S. Geological Survey \\ Marcia K. McNutt, Director
}

\author{
U.S. Geological Survey, Reston, Virginia: 2012
}

For more information on the USGS - the Federal source for science about the Earth, its natural and living resources, natural hazards, and the environment, visit http://www.usgs.gov or call 1-888-ASK-USGS.

For an overview of USGS information products, including maps, imagery, and publications, visit http://www.usgs.gov/pubprod

To order this and other USGS information products, visit http://store.usgs.gov

Any use of trade, product, or firm names is for descriptive purposes only and does not imply endorsement by the U.S. Government.

Although this report is in the public domain, permission must be secured from the individual copyright owners to reproduce any copyrighted materials contained within this report.

Suggested citation:

Pearse, A.T., and Selbo, S.M., 2012, Model of whooping crane energetics as foundation for development of a method to assess potential take during migration: U.S. Geological Survey Open-File Report 2012-1156, 13 p. 


\section{Acknowledgments}

This report is a product of a Quick Response Program project involving collaboration among Regions 2 and 6 of the U.S. Fish and Wildlife Service (USFWS) and the U.S. Geological Survey (USGS). Aaron Pearse also was supported by funds from the USGS Platte River Priority Ecosystem program and Northern Prairie Wildlife Research Center.

U.S. Fish and Wildlife Service employees that provided helpful information or assistance during the inception and development of the energetic model included Amelia Orton-Palmer, Laila Lienesch, Jim Dubovsky, Dave Sharp, Tom Stehn, Martha Tacha, and Greg Watson. Amelia Orton-Palmer, Larry Igl, Joshua Stafford, and Elizabeth Masden provided valuable comments to earlier drafts.

\section{Contents}

Acknowledgments ……...................................................................................................................

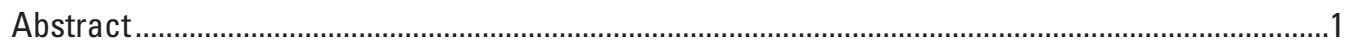

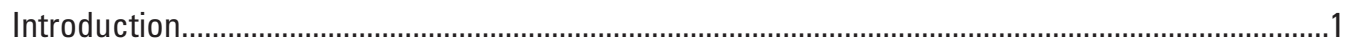

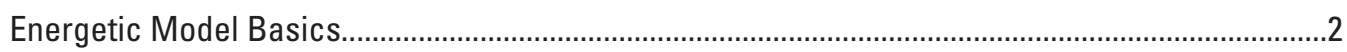

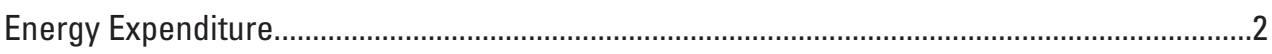

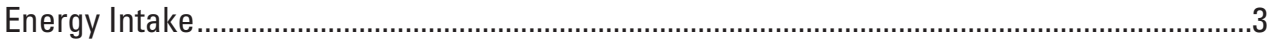

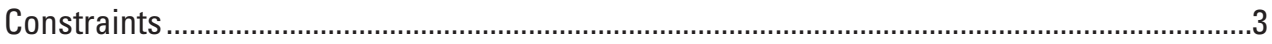

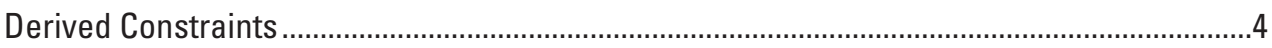

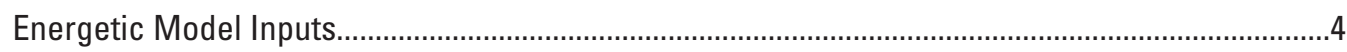

Power of Flight.

Whooping Crane Mass .............................................................................................................

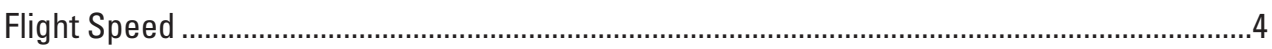

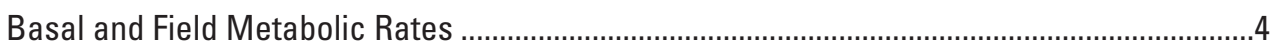

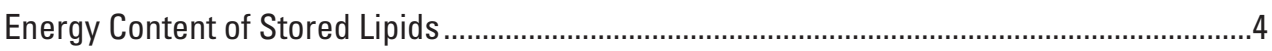

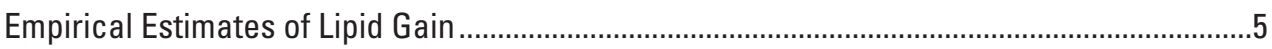

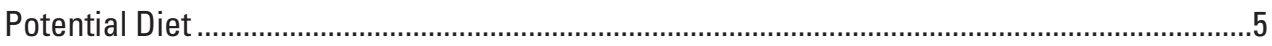

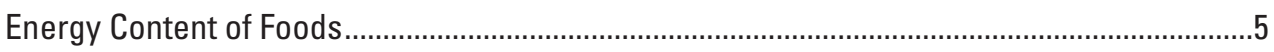

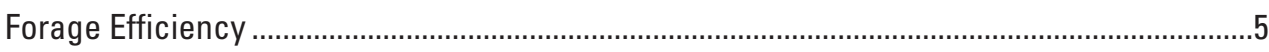

Maximum Food Consumption ..........................................................................................

Wet/Dry Weight Coefficients ...........................................................................................

Maximum Time per Foraging Bout and Bouts per Day.............................................................

Potential Management and Regulatory Applications ..................................................................

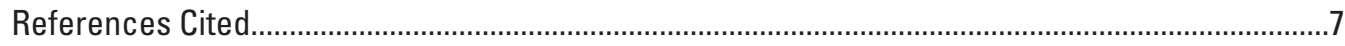

Appendix 


\section{Tables}

1. Potential food items that might be consumed by whooping cranes during migration

2. True metabolizable energy of potential diet items for migrating whooping cranes.

3. Estimated extra days whooping cranes would need to replenish lipid reserves from hypothetical model runs using varying additional distances whooping cranes might fly for an entire migration season.

\section{Conversion Factors}

SI to Inch/Pound

\begin{tabular}{lcl}
\hline \multicolumn{1}{c}{ Multiply } & By & \multicolumn{1}{c}{ To obtain } \\
\hline centimeter $(\mathrm{cm})$ & Length & \\
meter $(\mathrm{m})$ & 0.3937 & inch (in.) \\
kilometer $(\mathrm{km})$ & 3.281 & foot $(\mathrm{ft})$ \\
\hline & 0.6214 & mile $(\mathrm{mi})$ \\
\hline meter per second $(\mathrm{m} / \mathrm{s})$ & Flow rate & \\
kilometer per hour $(\mathrm{km} / \mathrm{h})$ & 3.281 & foot per second $(\mathrm{ft} / \mathrm{s})$ \\
& 0.6214 & mile per hour $(\mathrm{mi} / \mathrm{h})$ \\
\hline gram $(\mathrm{g})$ & Mass & \\
kilogram $(\mathrm{kg})$ & 0.03527 & ounce, avoirdupois $(\mathrm{oz})$ \\
& 2.205 & pound avoirdupois $(\mathrm{lb})$ \\
\hline joule $(\mathrm{J})$ & Energy & \\
watt $(\mathrm{W})$ & 0.738 & foot-pound $(\mathrm{ft} \cdot \mathrm{lb})$ \\
\hline
\end{tabular}




\title{
Model of Whooping Crane Energetics as Foundation for Development of a Method to Assess Potential Take during Migration
}

\author{
By Aaron T. Pearse and Sarena M. Selbo
}

\begin{abstract}
A whooping crane energetic model was developed as a component of a larger effort to ascertain potential take, as defined by the Endangered Species Act, of whooping cranes from proposed development of wind-energy infrastructure in the Great Plains of North America. The primary objectives of this energetic model were to (1) predict extra flight energy that whooping cranes may require to find suitable migration stopover sites if they are unable to use a primary site; and (2) express energy expended as additional time required to replenish lipid reserves used to fuel flight. The energetic model is based on three elements related to energy: expenditure of energy, intake of energy, and constraints to energy intake. The energetic model estimates each element and recognizes interactions among them. This framework will be most useful when integrated into a migration model that predicts incidence of avoidance of wind towers by whooping cranes and distances they might fly to find alternative stopover habitat. This report details work conducted in accordance with the U.S. Geological Survey and U.S. Fish and Wildlife Service Quick Response Program funded in fiscal year 2011 and will serve as a final report.
\end{abstract}

\section{Introduction}

Generation of electricity using wind-powered turbines constitutes an expanding component of renewable energy development in the United States. The Great Plains of North America has vast potential for wind-powered electricity generation and represents valuable territory to the wind-energy industry (Elliott and others, 1987). Federally endangered whooping cranes (Grus americana) migrate through the Great Plains during fall and spring, traveling between their breeding grounds at Wood Buffalo National Park in Canada and wintering grounds at and surrounding Aransas and Matagorda Island National Wildlife Refuges along the Gulf Coast of Texas, USA (Allen, 1952). During migrations, whooping cranes stop at suitable sites for relatively short periods of time (generally less than 10 days) to rest and feed (Lewis, 1995). The presence of infrastructure associated with wind-energy development in or near stopover sites poses a potential risk to whooping cranes. Nineteen wind companies are working with the U.S. Fish and Wildlife Service (USFWS) to develop a Great Plains habitat conservation plan (HCP), under the Endangered Species Act (ESA). This plan outlines efforts to minimize and mitigate effects from potential take of whooping cranes. Under the ESA, take of wildlife is defined as actions that harass, harm, pursue, hunt, shoot, wound, kill, trap, capture, or collect endangered species and include attempts made to engage in any such conduct (Endangered Species Act, 1973). This effort will partly depend on a risk assessment of take of migrating whooping cranes and the effects of such take. The results of that assessment will inform appropriate siting and operations guidance to developers of wind-energy projects to avoid or minimize adverse impacts to whooping cranes.

Experts have suggested whooping cranes prefer stopover habitat without vertical obstructions of sight (Armbruster, 1990); thus, whooping cranes may avoid landing at otherwise suitable sites where wind turbines occur. The development of wind farms may, in some cases, negatively affect energy budgets of whooping cranes during migration, when seeking alternative stopover habitat increases energy demands. Additionally, presence of vertical obstructions such as wind towers may increase migration flight distances if birds avoid structures (Masden and others, 2009). The development of the HCP's risk assessment model will partly rely on an understanding of whooping crane energy budgets during migration. To meet that purpose, funds associated with the Quick Response Program were provided to a team of biologists from U.S. Geological Survey (USGS) and the USFWS to develop a special-use energetic model of whooping crane migration, as described in this report. The primary objectives of this energetic model were to (1) predict extra flight energy that whooping cranes use in finding suitable stopover sites if they are unable to use a primary site; and (2) express energy expended as additional time required to replenish lipid reserves used to fuel flight. This additional time may cause delays in migration that could 
lead to whooping cranes arriving late to the breeding grounds, and ultimately sublethal impacts to fitness. If these effects were attributed to specific causes (for example, presence of a wind-energy facility), they could be considered take under the Endangered Species Act. Direct mortality because of wind structures (for example, collisions) will be addressed as part of the more comprehensive HCP.

Because this energetic model was developed to be a component of the larger HCP risk assessment effort, it may have limited use as a stand-alone product beyond offering insight into basic constraints whooping cranes must overcome during migration. The energetic model was developed under the assumption that certain predictions from a migration model for whooping cranes would be used as input parameters in the energetic model. These input parameters include incidence of avoiding wind turbines and distances whooping cranes might fly to circumvent them. Thus, this energetic model was not constructed to determine if whooping cranes avoided wind turbines or to determine distances they might fly to avoid towers and other structures. Integration with a migration model is necessary for expanded use (for example, Masden and others, 2012). The energetic model does have flexibility to quantify extra energy expended as lipids used to sustain flight or an expectation of days needed to replenish used lipids; therefore, the energetic model could be used to estimate, over an entire migration, number of days whooping cranes were delayed because of foraging to replenish energy stores, a lipid deficit after reaching breeding grounds, or a combination of these potential impacts. Practitioners would need to supply predicted behavioral responses (for example, stay at a site and forage as compared to continued migration) to take advantage of this plasticity.

A model "reflects an abstraction of key features of a system into a simple set of ideas, words, or equations that represents the system" (Williams and others, 2002, page 22). Models are approximations of truth that are intended to capture key features of systems, while excluding unnecessary detail; therefore, as with any model, this energetic model does not contain all of the complexities of individuals interacting with their environment. Output from a model is only as valid and reliable as the input parameters, assumptions, and constraints used to create it. Model developers should be diligent in documenting these components. Because relevant data specific to the whooping crane were lacking, parameters and relations developed from other species in the modeling process were used. Future research likely will provide more applicable parameter estimates, and practitioners may wish to modify input parameters as additional data become available. As models and simulations do not completely represent complex systems, their success can be measured by their ability to achieve an intended purpose - the objective(s) of the modeling effort.

The remainder of this report comprises four sections. An initial section describes basic energetic model design, which comprises a description of how and why it was constructed and a partial list of limitations inherent in the current version.
The following section includes description of input parameters used and full listing of citations. Assumptions used in development also are indicated. The next section provides examples of potential management and regulatory application of output. Finally, the energetic model is presented in a spreadsheet for ease of use, accessibility, and transparency for those interested in inspecting how it generates output (appendix A). Executing the energetic model with a programming language may be more useful when interfacing with a migration model.

\section{Energetic Model Basics}

Energetics provide a useful framework to describe how organisms make a living in their environment. All organisms must acquire and expend energy to sustain life and conduct normal activities. This energetic model is based on three elements related to energy: expenditure of energy, intake of energy, and constraints to energy intake. The energetic model was developed to calculate each element, provide for interactions among elements, and find balance among them. This section provides explanation of how and why each element was selected and calculated, and how each fits into the overall energetic model to produce outputs. Additionally, this section provides a general description of methodology, whereas the following section includes detailed documentation of input parameters and citations.

\section{Energy Expenditure}

Whooping cranes use several methods of flight during migration, such as thermal spiraling coupled with gliding and forward-flapping flight (Kuyt, 1993). Flight powered by soaring and gliding, which was the most frequent method observed for migrating whooping cranes (Kuyt, 1993), requires greatly reduced energy compared to forward-flapping flight (Pennycuick, 1989). When thermal activity declined at dusk, whooping cranes used forward-flapping flight at relatively low altitudes to progress to a stopover site (Kuyt, 1993). This energetic model was developed based on the assumption that whooping cranes migrating diurnally may perceive wind turbines as obstructions at primary stopover sites and fly some extra distance (that is, a distance they would not have flown if the wind farm was not there) to find a suitable alternative stopover site. Thus, any energy used before avoidance behavior is considered part of their unaltered migration and may include soaring or flapping flight.

To estimate extra energy used to avoid structures, an empirical method was used that determines power required for forward-flapping flight only, the method of flight expected of whooping cranes late in the day. This method relies on a derived equation from results of multiple studies of birds, wherein direct measurements of energy requirements for flight were measured (Norberg, 1996; Castro and Myers, 1988). An empirical equation using only body mass was presented 
by Norberg (1996), which described 86 percent of variation in flight energy requirements $(n=33)$. Although a simple and useful relation, the heaviest bird included in the sample was slightly more than 1 kilogram $(\mathrm{kg})$; thus, calculating the power of flight for a 7.2-kg whooping crane using this equation is tenuous. Therefore, using a measure of flight energy from birds closer to the size of a whooping crane would be recommended, if it becomes available. Flight energy initially is expressed in kiloJoules per second $(\mathrm{kJ} / \mathrm{s})$ and the energetic model converts this into energy consumed over a distance by incorporation of an estimate of flight speed. This estimate of energy use [kiloJoules per kilometer $(\mathrm{kJ} / \mathrm{km})$ ] is used directly to determine extra energy required for flight. Three alternative empirical methods were presented by Castro and Myers (1988), using body mass and body mass with structural measurements to improve model fit. When using their best available method, which incorporated body mass and wing length, resulting flight energy requirements for a 7.2-kg bird with a wing length of 60 centimeters $(\mathrm{cm})$ (Lewis, 1995) were nearly twice as much as that calculated using the mass only equation presented in Castro and Myers (1988) or the mass only equation from Norberg (1996). Therefore, it was suspected that available wing measurements did not properly represent wing length needed in the empirical flight energy equation.

At the end of a migration day, whooping cranes are likely to use lipid stores to fuel flight because other sources of energy have already been expended; thus, the energetic model calculates lipids used to fuel extra flight by converting lipids to energy, assuming that lipid catabolism is not 100 percent efficient. In the most simplistic version, lipids used to fuel extra flight must be replaced before further migration can occur. The energy required to synthesize this amount of lipids is calculated based on the energy content of lipids, taking into account that synthesis of tissue is not 100 percent efficient. Additionally, the energetic model can provide output for any conceivable "extra distance", yet it may be reasonable to assume that whooping cranes would rarely fly greater than 200 kilometers $(\mathrm{km})$ after a day of migration, given that it may take them $\sim 4.5$ hours (hr) to cover $200 \mathrm{~km}$ at a flight speed of 12 meters per second $(\mathrm{m} / \mathrm{s})$ (43 kilometers per hour $(\mathrm{km} / \mathrm{hr})$; Tacha and others, 1992).

An alternative method for determining power required for flight, which uses theoretical equations has been described by Pennycuick (1989). Masden and others (2010) used this method to calculate energetic costs of avoiding current and proposed wind farms for multiple species of seabirds. The method represents a detailed approach to calculating many aspects of flight performance and thus requires detailed input parameters, namely structural measurements of birds. Currently, measurements made with the exacting methods needed to run the model with reasonable accuracy are not available. Using estimates, the model predicts the cost of flight for a $7.2-\mathrm{km}$ whooping crane at 638 watts, or $29.8 \mathrm{~kJ} / \mathrm{km}$ and also predicts an optimal flight speed of $21.4 \mathrm{~m} / \mathrm{s}$. Using these two model-derived values, the resultant energy requirement represents a 25 percent increase in energy expense compared with the current method. Yet, using a wingspan of less than 20 percent difference from an estimated value (Lewis, 1995), estimated flight energy would be the same from each model. Because the flight program is sensitive to structural measurements, reliable measurements are needed before incorporating into the whooping crane energetic model.

Basal metabolic rate (BMR) is the measure of energy birds expend to maintain themselves. BMR can be estimated using a mathematical relation to body mass. Energy expenditure more than BMR is necessary to perform daily activities (for example, movement, thermoregulation); this energetic model incorporates a multiplier more than BMR to accommodate these functions. Overall energetic demand or field metabolic rate can be considered a fixed cost of living. Basal and field metabolic rates are known to vary with season, temperature, diet, and other factors (see Carey, 1996). These additional complexities were not included in the energetic model because it was not known how these parameters might affect metabolic rates of whooping cranes, leading to unknown error in calculations. The method used has been used in numerous situations, mainly for determining energetic needs of nonbreeding waterfowl in North America (for example, Reinecke and Loesch, 1996).

\section{Energy Intake}

Whooping cranes acquire energy by consuming food. Availability of various crops in the Great Plains and documented habitat use provide some information as to what types of foods whooping cranes may encounter and consume during migration. Minimal information exists as to what foods whooping cranes actually use or in what proportion foods are consumed. The energetic model allows for a mixed diet of 11 foods. Additional foods can be easily added. All foods have three basic parameters associated with them: (1) the true metabolizable energy of a food represents the energetic content of the food that birds can assimilate [kiloJoules per gram (kJ/g) dry mass]; (2) a factor that allows for conversion between wet and dry weights when necessary; and finally, (3) a rate of food consumption grams per minute $(\mathrm{g} / \mathrm{min})$ provides an estimate of how much energy birds can consume under a time constraint. Model practitioners can vary diet by changing percentages of dry mass consumed. The energetic model calculates weighted averages of energy content and consumption rate for use in the next portion of the energetic model.

\section{Constraints}

Animals are limited in how much energy they can intake in a set period of time. The energetic model provides for two basic ways in which to implement constraints. An integrated approach allows the model practitioner to supply a value for maximum energy intake, expressed as lipid acquisition per day. An estimate of lipid gain per day is not available 
specifically for whooping cranes; thus, a value based on estimates derived from other species must be used.

The energetic model also includes calculations of potential lipid acquisition rates per day using two potential mechanisms. If food intake rate is high, animals may be constrained by the amount of food their digestive system can process in a day. This can be considered a food-based constraint and approximated by a maximum amount of food that can be consumed. If the food intake rate is relatively low, then animals may be limited by the amount of time they can put towards foraging in a day; this can be considered a time-based constraint represented by total minutes per foraging bout or day that birds can feed. Because the energetic model has great flexibility in users defining the animal's diet, it is not known initially which factor will limit energy intake. The energetic model provides results based on both mechanisms.

\section{Derived Constraints}

After calculation of energetic demand and intake based on constraints, the energetic model makes predictions regarding the extra time needed to reconcile needs. Initially, the energetic model requires that a certain amount of food must be consumed to meet basic requirements (that is, field metabolic rate) and any intake above the base level can be used to replace lipids. Maximum energy that birds can intake relates to the two constraints set up above. This value is converted to lipids that can be synthesized per day and compared with the amount that the whooping crane must acquire based on extra flight distances. This results in the number of foraging bouts that the bird must initiate to meet demand and, assuming they must stay all day if required to initiate just one bout, how many extra days they must stay to meet demand. For example, if a bird must consume enough food to synthesize 20 grams (g) of lipids (extra energy demand) and they can acquire $10 \mathrm{~g}$ of lipids per foraging bout, then they must stay for two bouts, which can be completed in 1 day under the assumption that they feed twice daily. The energetic model provides output based on both constraints (food and time) and the larger of the two values can be interpreted as the overall output.

\section{Energetic Model Inputs}

\section{Power of Flight}

The metabolic power required for flight was estimated using an equation derived from a combination of multiple datasets, wherein energy required for flight was derived using multiple techniques including respiration data from wind tunnel experiments, time-energy budget studies, and mass loss (Norberg, 1996).

$$
\text { Power of flight }=573 M^{0.813}
$$

where

power is measured in watts $(\mathrm{J} / \mathrm{s})$ and $M \quad$ is mass of a bird (kg).

This equation does not include structural measurements of birds because accurate measurements do not exist for whooping cranes at this time. An alternative model has been described by Pennycuick (1989).

\section{Whooping Crane Mass}

Lewis (1995) reported captive males weighing $7.3 \mathrm{~kg}$, captive females weighing $6.4 \mathrm{~kg}$, and wild adults between 7.1 and $7.9 \mathrm{~kg}$. The energetic model initially was set at $7.2 \mathrm{~kg}$, which represented the median between the two most extreme values. This value may be supplemented with masses of whooping cranes caught through trapping efforts in conjunction with the Global Positioning System (GPS) satellite marking project by the USGS, USFWS, and other research partners.

\section{Flight Speed}

For this report a value of $43 \mathrm{~km} / \mathrm{h}$ was used, which represented a median value reported for sandhill cranes (Grus canadensis; $12 \mathrm{~m} / \mathrm{s}$ ) by Tacha and others (1992). Additional data may become available from the GPS satellite marking project. If using the Flight Program (Pennycuick, 1989), practitioners may use the minimum flight speed reported in the program results.

\section{Basal and Field Metabolic Rates}

The energetic model uses a calculation for basal metabolic rate generalized for all birds from Reynolds and Lee (1996):

$$
B M R=1.311 M^{0.633}
$$

where

$$
\begin{aligned}
& M \text { is a bird's mass measured in grams and } \\
& B M R \text { is estimated in kilocalories per day and } \\
& \text { converted to } \mathrm{kJ} / \text { day }(1 \mathrm{kcal}=4.187 \mathrm{~kJ}) .
\end{aligned}
$$

A multiplier of $3 \times B M R$ is used to account for the cost of free living and to derive a field metabolic rate (Prince, 1979).

\section{Energy Content of Stored Lipids}

A value of $39.8 \mathrm{~kJ} / \mathrm{g}$ was used as energy content of stored lipids (Kendeigh and others, 1977). Lipids are not biosynthesized with 100 percent efficiency; thus, 75 percent metabolic efficiency was used (Weathers, 1996). Finally, catabolism of lipids also is not completely efficient. A value of 95 -percent efficiency was used, because Stryer (1995) reported that the yield from oxidation of fatty acids is about $9 \mathrm{kcal} / \mathrm{g}$ $(37.7 \mathrm{~kJ} / \mathrm{g})$. 


\section{Empirical Estimates of Lipid Gain}

Numerous estimates of average lipid gain with time have been reported for waterfowl and larger waterbirds. Krapu and others (1985) found that lesser sandhill cranes gained 13-16 $\mathrm{g}$ of lipids per day during spring staging in the central Platte River Valley and that greater sandhill cranes gained 25 grams per day (g/d) (G. L. Krapu, unpub. data). Greater white-fronted geese (Anser albifrons) acquired lipids at a rate of $14 \mathrm{~g} / \mathrm{d}$, while staging in the Rainwater Basin of Nebraska (Krapu and others, 1995). Spring-staging snow geese (Chen caerulescens) gained $17.5 \mathrm{~g}$ of lipids per day in Saskatchewan, Canada. Finally, Raveling (1979) reported Canada geese (Branta canadensis) gained 16-22 g/d. Of all of these reports, greater sandhill cranes are most closely related to whooping cranes phylogenetically and structurally; therefore, lipid gain for greater sandhill cranes was used.

\section{Potential Diet}

Potential food items were determined from feeding studies and habitat use patterns of whooping cranes (table 1 and references therein). Potential staging sites that may contain these foods should be viewed in the context of current agriculture practices. Substantial changes in food resources and availability have occurred across the Great Plains in the past 50 years, with indications of continued changes in the future (for example, Krapu and others, 2004, Pearse and others, 2010).

\section{Energy Content of Foods}

Food items have various energetic contents and animals are able to extract different amounts of energy from them. True metabolizable energy content of foods that whooping cranes might consume during migration are reported in table 2 .

\section{Forage Efficiency}

A value of $0.7 \mathrm{~g} / \mathrm{min}$ was used as a rate that whooping cranes could acquire food once they find a foraging patch with available food. This value is based on observations of common cranes (Grus grus) wintering in Spain feeding on cereal crops (Alonso and Alonso, 1992). Forage rates for corn, soybeans, and field peas are likely higher because they are larger seeds; 150 percent higher forage rate than for cereals was used (assumption without supporting citation). Forage rate for protein and invertebrates is likely much less given the distribution of these resources and that the rate is based on a dry mass basis. Forage rate was reduced by 80 percent (assumption without supporting citation). These values are without strong empirical support and are important factors in determining the amount of lipids that birds can acquire per day from the perspective of the time constraint. Using a 100 percent corn diet as an example, decreasing foraging rate of corn by 25 percent $(0.79 \mathrm{~g} / \mathrm{min})$, decreased estimated lipid gain per day from 107 to $59 \mathrm{~g}$ (45 percent decrease). Decreasing corn foraging rate 50 percent $(0.53 \mathrm{~g} / \mathrm{min})$, lead to a 90 percent decrease in estimated lipid gain per day. Additional research is needed to better understand diet choice and forage efficiency of migrating whooping cranes. Finally, these values can be manipulated to represent relatively more or less rich patches of forage that might be available based on different scenarios.

Table 1. Potential food items that might be consumed by whooping cranes during migration.

[ND, North Dakota; SD, South Dakota; NE, Nebraska; KS, Kansas; OK, Oklahoma; TX,Texas]

\begin{tabular}{llr}
\hline \multicolumn{1}{c}{ Potential item } & \multicolumn{1}{c}{ Source(s) } & Potential staging sites $^{{ }^{1}}$ \\
\hline Corn (Zea mays) & Shields and Benham, 1969; Howe, 1989; Lingle and others, 1991 & ND, SD, NE, KS, OK, TX \\
Soybean (Glycine max) & Lingle and others, 1991 & ND, SD, NE, KS, OK, TX \\
Wheat grain (Triticum aestivum) & Shields and Benham, 1969; Howe, 1989; Johns and others, 1997 & All \\
Wheat shoots & Uhler and Locke, 1970 & All \\
Peas (Pisum sativum) & Shields and Benham, 1969 & SD, ND \\
Sorghum grain (Sorghum bicolor) & Shields and Benham, 1969; Howe, 1989; Lingle and others, 1991 & KS, OK \\
Chufa tuber (Cyperus esculentus) & Uhler and Locke, 1970; Howe, 1989 All \\
Barnyard grasses (Echinochloa spp.) & Howe, 1989 & All \\
Smartweed seeds (Polygonum spp.) & Howe, 1989 & All \\
Protein & Allen, 1952 & All \\
Invertebrates & Uhler and Locke, 1970 & All \\
\hline
\end{tabular}

${ }^{1}$ Represents probable locations where food items might be found. 
Table 2. True metabolizable energy of potential diet items for migrating whooping cranes.

$[\mathrm{kJ} / \mathrm{g}$; kiloJoule per gram]

\begin{tabular}{lcl}
\hline \multicolumn{1}{c}{ Potential item } & \multicolumn{1}{c}{$\mathbf{k J / g}$} & \multicolumn{1}{c}{ Source } \\
\hline Corn & 16.3 (Canimal model) & \\
Soybean & 14.9 (Canada goose) & Petrie and others, 1998 \\
Wheat grain & 16.1 (Canada goose) & Joyner and others, 1987 \\
Wheat shoots & 10.1 (Canada goose) & Petrie and others, 1998 \\
Field peas & $12.3-15.62$ (poultry) & Castell and others, 1996 \\
Sorghum grain & 15.7 (Canada goose) & Petrie and others, 1998 \\
Chufa tuber & 16.9 (Canada goose) & Petrie and others, 1998 \\
Wild millet & 13.8 (Canada goose) & Petrie and others, 1998 \\
Smartweed & 6.7 (Canada goose) & Petrie and others, 1998 \\
$\quad$ seeds & 17.1 (generic bird) & Bell, 1990 \\
Protein & 17.2 (generic bird) & Bell, 1990 \\
Invertebrates &
\end{tabular}

\section{Maximum Food Consumption}

The energetic model estimates maximum food consumption based on an allometric equation that was used in Amano and others (2004) for an optimal foraging model for geese. The intercept of the equation is based on brant geese (Branta bernicla) weighing $1.5 \mathrm{~kg}$ and able to consume $150 \mathrm{~g}$ fresh weight of food (Prop and Deerenberg, 1991). The exponent in the equation was based on Ricklefs (1996).

\section{Wet/Dry Weight Coefficients}

These coefficients were needed to convert food consumed from wet to dry mass. Values of 1.1 for seeds (Amano and others 2004), 5.2 for vegetation (Amano and others, 2004), and 2.3 for invertebrates (that is, based on the assumption that they are 60-80 percent water; Chapman, 1998) were used.

\section{Maximum Time per Foraging Bout and Bouts per Day}

During late April, there are 12 plus hours of daylight, depending on latitude (vernal equinox); thus, the energetic model was developed assuming birds could spend up to 10 hours per day foraging. This is an assumption with no supporting citation. Spring-staging sandhill cranes fed in croplands during mid-morning and late afternoon (U.S. Fish and Wildlife Services, 1981); thus, it was assumed that migrating whooping cranes might have two foraging bouts per day.

\section{Potential Management and Regulatory Applications}

Under the ESA, take of wildlife is defined as actions that harass, harm, pursue, hunt, shoot, wound, kill, trap, capture, or collect endangered species and include attempts made to engage in any such conduct (Endangered Species Act, 1973). Harm is further defined as an act which actually kills or injures wildlife. Such acts may include substantial habitat modification or degradation where such action actually kills or injures wildlife by substantially impairing essential behavioral patterns, including breeding, feeding, or sheltering. Incidental take is take that results from, but is not the purpose of, an otherwise lawful activity (that is, wind-energy project). Incidental take of an endangered species is a prohibited action that must be exempted or permitted through a regulatory process (Endangered Species Act, 1973).

To provide an indication of how this energetic model could be used to determine effects to migration chronology, leading to incidental take, hypothetical scenarios are presented where whooping cranes are assumed to travel extra distances of 10-200 km during their entire migration. Total flight distance during migration is estimated to be $4,000 \mathrm{~km}$; therefore, these hypothetical distances reflect $0.3-5$ percent increases in overall flight distance. For these scenarios, three basic diets were used, which reflect different landscapes that whooping cranes might encounter during migration. A corn-dominated diet consisting of 70 percent corn, 10 percent chufa tuber, 10 percent wild millet, 5 percent smartweed, and 5 percent protein might be found in corn-growing regions within the U.S. portion of the migration corridor. A wheat-dominated diet consisting of 60 percent wheat seeds, 20 percent field peas, 10 percent wild millet, 5 percent chufa tubers, and 5 percent protein represents portions of the corridor without substantial corn agriculture. Finally, a diet consisting entirely of wetland foods (that is, 35 percent chufa, 30 percent millet, 25 percent smartweed, 10 percent protein) was included, which could be available at any stopover site.

Overall energy content of each diet differed based on their relative composition. The corn-dominated diet had an average estimated energy content of $13.5 \mathrm{~kJ} / \mathrm{g}$ and foraging efficiency rate of $14.5 \mathrm{kiloJ}$ oules per minute $(\mathrm{kJ} / \mathrm{min})$. The wheat-dominated diet had similar energy content $(13.4 \mathrm{~kJ} / \mathrm{g})$ but lower foraging efficiency of $11.4 \mathrm{~kJ} / \mathrm{min}$. The diet consisting of wetland foods had the lowest average energy content and foraging efficiency rate $(11.1 \mathrm{~kJ} / \mathrm{g} ; 8.4 \mathrm{~kJ} / \mathrm{min})$. Accordingly, the energetic model predicted whooping cranes would be delayed the shortest amount of time if they consumed the most efficient diet dominated by corn, and would require the longest time when consuming exclusively a wetland-based diet (table 3).

It is important to note that this energetic model should not be used exclusively to define or rank stopover sites, because it only incorporates foraging resources that might be available at a potential stopover site. Minimally, a stopover site 
Table 3. Estimated extra days whooping cranes would need to replenish lipid reserves from hypothetical model runs using varying additional distances whooping cranes might fly for an entire migration season.

$[\mathrm{km}$, kilometer $]$

\begin{tabular}{cccc}
\hline $\begin{array}{c}\text { Extra } \\
\text { distance } \\
(\mathbf{k m})\end{array}$ & $\begin{array}{c}\text { Corn-dominated } \\
\text { diet }\end{array}$ & $\begin{array}{c}\text { Wheat-dominated } \\
\text { diet }\end{array}$ & $\begin{array}{c}\text { Wetland-foods } \\
\text { diet }\end{array}$ \\
\hline 10 & 1 & 1 & 1 \\
50 & 1 & 1 & 4 \\
100 & 1 & 2 & 8 \\
200 & 2 & 4 & 16 \\
\hline
\end{tabular}

must include a safe roost site. Specific characteristics of roost sites have been developed and include wetlands with areas of shallow water, with minimal visual obstructions, situated in areas of relatively low disturbance, and in a matrix of potential foraging habitats (Armbruster, 1990). Indeed, croplands in isolation would not likely be considered suitable stopover habitat.

Based on these hypothetical scenarios, take of whooping cranes may occur through harm if whooping cranes avoid large structures (for example, group of wind turbines) and, in essence, lose suitable stopover habitat. Adverse effects may occur if stopover sites are avoided and whooping cranes fly extra distances to find suitable habitat without large structures. Flying longer distances requires additional energy expenditure and would equate to an extra day or days to replenish energy reserves (table 3). Extra days foraging and replacing depleted energy reserves may result in delays in reaching whooping crane breeding grounds. This delay may equate to harm to whooping cranes if that delay translates into reduced breeding success (that is, less time to hatch and fledge young). Additionally, whooping cranes may continue migration and arrive on the breeding grounds with a lipid deficit. In this instance, they may either spend extra days building required reserves to nest or their reproductive effort could be reduced (for example, clutch size, egg mass). Thus, incidental take may occur through decreased reproductive output through multiple mechanisms related indirectly to loss and avoidance of otherwise suitable migratory habitat.

The energetic model described within lays out a foundation for ESA practitioners and project proponents to more fully understand and evaluate potential risk associated with windenergy projects on the landscape. The use of this energetic model with others being developed may assist in estimating potential incidental take to the whooping crane and, more importantly, may help guide discussions about conservation measures that can be implemented across the landscape to avoid, minimize, and mitigate potential impacts to whooping cranes.

\section{References Cited}

Alisauskas, R.T., 2002, Arctic climate, spring nutrition, and recruitment in midcontinent lesser snow geese: Journal of Wildlife Management, v. 66, p. 181-193.

Allen, R.P., 1952, The whooping crane: Resource Report 3: New York, National Audubon Society, 246 p.

Alonso, J.C., and Alonso, J.A., 1992, Daily activity and intake rate patterns of wintering common cranes Grus grus: Ardea, v. 80 , p. $343-351$.

Amano, T., Ushiyama, K., Fujita, G., and Higuchi, H., 2004, Alleviating grazing damage by white-fronted geese: an optimal foraging approach: Journal of Applied Ecology, v. 41, p. 675-688.

Armbruster, M.J. 1990. Characterization of habitat used by whooping cranes during migration: U.S. Fish and Wildlife Service, Biological Report 90, 16 p.

Bell, G.P., 1990, Birds and mammals on an insect diet: a primer on diet composition analysis in relation to ecological energetics: Studies in Avian Biology v. 13, p. 416-422.

Carey, C., ed., 1996, Avian energetics and nutritional ecology: New York, Chapman \& Hall, 543 p.

Castell, A.G., Guenter, W., and Igbasan, F.A., 1996, Nutritional value of peas for nonruminant diets: Animal Feed Science Technology, v. 60, p. 209-227.

Castro, G., and Myers, J.P., 1988, A statistical method to estimate the cost of flight in birds: Journal of Field Ornithology, v. 59, p. $369-380$.

Chapman, R.F., 1998, The insects: structure and function (4th ed.): Cambridge, Cambridge University Press, 770 p.

Elliott, D.L., Holladay, C.G., Barchet, W.R., Foote, H.P., and Sandusky, W.F., 1987, Wind energy resource atlas of the United States: Pacific Northwest Laboratory, accessed June 2, 2012, at http://rredc.nrel.gov/wind/pubs/atlas/.

Endangered Species Act, Public Law 93-205, Dec. 28, 1973, as amended through Public Law 107-136, Jan. 24, 2002, 47 p.

Howe, M.A., 1989, Migration of radio-marked whooping cranes from the Aransas-Wood Buffalo population: patterns of habitat use, behavior, and survival, Technical Report 21: Washington, D.C., U.S. Fish and Wildlife Service, 33 p.

Johns, B.W., Woodsworth, E.J., and Driver, E.A., 1997, Habitat use by migrant whooping cranes in Saskatchewan: Proceedings of the North American Crane Workshop, v. 7 , p. 123-131. 
Joyner, D.E., Jacobson, B.N., and Arthur, R.D., 1987, Nutritional characteristics of grains fed to Canada geese: Wildfowl, v. 38, p. 89-93.

Kendeigh, S.C., Dol'nik, V.R., and Gavrilov, V.M., 1977, Avian energetics, in Pinowski, J., and Kendeigh, S.C., eds., Granivorous birds in ecosystems: Cambridge, United Kingdom, Cambridge University Press, p. 129-204.

Krapu, G.L., Brandt, D.A., and Cox, Jr., R.R., 2004, Less waste corn, more land in soybeans, and the switch to genetically modified crops: trends with important implications for wildlife management: Wildlife Society Bulletin, v. 32, p. $127-136$.

Krapu, G.L., Iverson, G.C., Reinecke, K.J., and Boise, C.M., 1985, Fat deposition and usage by arctic-nesting sandhill cranes during spring: The Auk, v. 102, p. 362-368.

Krapu, G. L., Reinecke, K.J., Jorde, D.G., and Simpson, S.G., 1995, Spring-staging ecology of midcontinent greater white-fronted geese: Journal of Wildlife Management, v. 59, p. 736-746.

Kuyt, E., 1993., Aerial radio-tracking of Whooping Cranes migrating between Wood Buffalo National Park and Aransas National Wildlife Refuge, 1981-84: Canadian Wildife Service Occasional Paper 74, 50 p.

Lewis, J.C. 1995., Whooping crane (Grus americana), in Poole, A., ed., The birds of North America. Ithaca, New York, Cornell Lab of Ornithology, 28 p.

Lingle, G.R., Wingfield, G.A., and Ziewitz, J.W., 1991, The migration ecology of whooping cranes in Nebraska, U.S.A. in Harris, J., ed., Proceedings of the International Crane Foundation Workshop: Qiqihar, Heilongjiang Province, People's Republic of China, p. 395-401.

Masden, E.A., Haydon, D.T., Fox, A.D., and Furness, R.W., 2010, Barriers to movement: modeling energetic costs of avoiding marine wind farms amongst breeding seabirds: Marine Pollution Bulletin, v. 60, p. 1,085-1,091.

Masden, E.A., Haydon, D.T., Fox, A.D., Furness, R.W., Bullman, R., and Desholm, M., 2009, Barriers to movement: impacts of wind farms on migrating birds: ICES Journal of Marine Science, v. 66, p. 746-753.

Masden, E.A., Reeve, R., Desholm, M., Fox, A.D., Furness, R.W., and Haydon, D.T., 2012, Assessing the impact of marine wind farms on birds through movement modelling: Journal of the Royal Society, doi:10.1098/rsif.2012.0121.

Norberg, U.M., 1996, Energetics of flight, in Carey, C., ed., Avian energetics and nutritional ecology: New York, Chapman \& Hall, p. 199-249.
Pearse, A.T., Krapu, G.L., Brandt, D.A., and Kinzel, P.J., 2010, Changes in agriculture and abundance of snow geese affect carrying capacity of sandhill cranes in Nebraska: Journal of Wildlife Management, v. 74, p. 479-488.

Pennycuick, C.J., 1989, Bird flight performance: a practical calculation manual: New York, Oxford University Press, $153 \mathrm{p}$.

Petrie, M.J., Drobney, R.D., and Graber, D.A., 1998, True metabolizable energy estimates of Canada goose foods: Journal of Wildlife Management, v. 62, p. 1,147-1,152.

Prince, H.H., 1979, Bioenergetics of postbreeding dabbling ducks, in Bookhout, T.A., ed., Waterfowl and wetlands: an integrated review. Proceedings of the 1977 Symposium of the North Central Section of the Wildlife Society: Madison, Wisconsin, La Crosse Printing Co., p. 103-117.

Prop, J., and Deerenberg, C., 1991, Spring staging in brent geese Branta bernicla: feeding constraints and the impact of diet on the accumulation of body reserves: Oecologia, v. 87, p. 19-28.

Raveling, D.G., 1979, The annual cycle of body composition of Canada geese with special reference to control of reproduction: The Auk, v. 96, p. 234-252.

Reinecke, K.J., and Loesch, C.R., 1996, Integrating research and management to conserve wildfowl (Anatidae) and wetlands in the Mississippi alluvial valley, USA: Gibier Faune Sauvage, Game and Wildlife, v. 13, p. 927-940.

Reynolds, P.S., and Lee, III, R.M., 1996, Phylogenetic analysis of avian energetics: passerines and nonpasserines do not differ: American Naturalist, v. 147, p. 735-759.

Ricklefs, R.E., 1996, Morphometry of the digestive tracts of some passerine birds: Condor, v. 98, p. 279-292.

Shields, R.H., and Benham, E.L., 1969, Farm crops as food supplements for whooping cranes: Journal of Wildlife Management, v. 33, p. 811-817.

Stryer, L., 1995., Biochemistry (4th ed.), New York, W. H. Freeman and Company, 1,064 p.

Tacha, T.C., Nesbitt, S.A., and Vohs, P.A., 1992, Sandhill crane (Grus canadensis), in Poole, A., ed., The birds of North America. Ithaca, New York, Cornell Lab of Ornithology, 24 p.

Uhler, F.M., and Locke, L.N., 1970, A note on the stomach contents of two whooping cranes: Condor, v. 72, p. 246.

U.S. Fish and Wildlife Service., 1981, The Platte River ecology study special research report: U.S. Fish and Wildlife Service, Jamestown, ND, accessed June 4, 2012, at http:// www.npwrc.usgs.gov/resource/habitat/plriveco/index.htm. 
Weathers, W.W., 1996, Energetics of postnatal growth, in Carey, C., ed., Avian energetics and nutritional ecology. New York, Chapman \& Hall, p. 461-496.

Williams, B.K., Nichols, J.D., and Conroy, M.J., 2002, Analysis and management of animal populations, San Diego, California, Academic Press, 817 p. 



\section{Appendix}

The following figures are screenshots of a spreadsheet program used to implement the energetic model described in this report. Certain input parameters such as "extra distance traveled" (cell B14) and "\% diet (dry mass)" (cells C24-C34) were populated with values for illustration purposes only. 


\section{Appendix 1. Screen Shots of Energetic Model Showing Calculations}

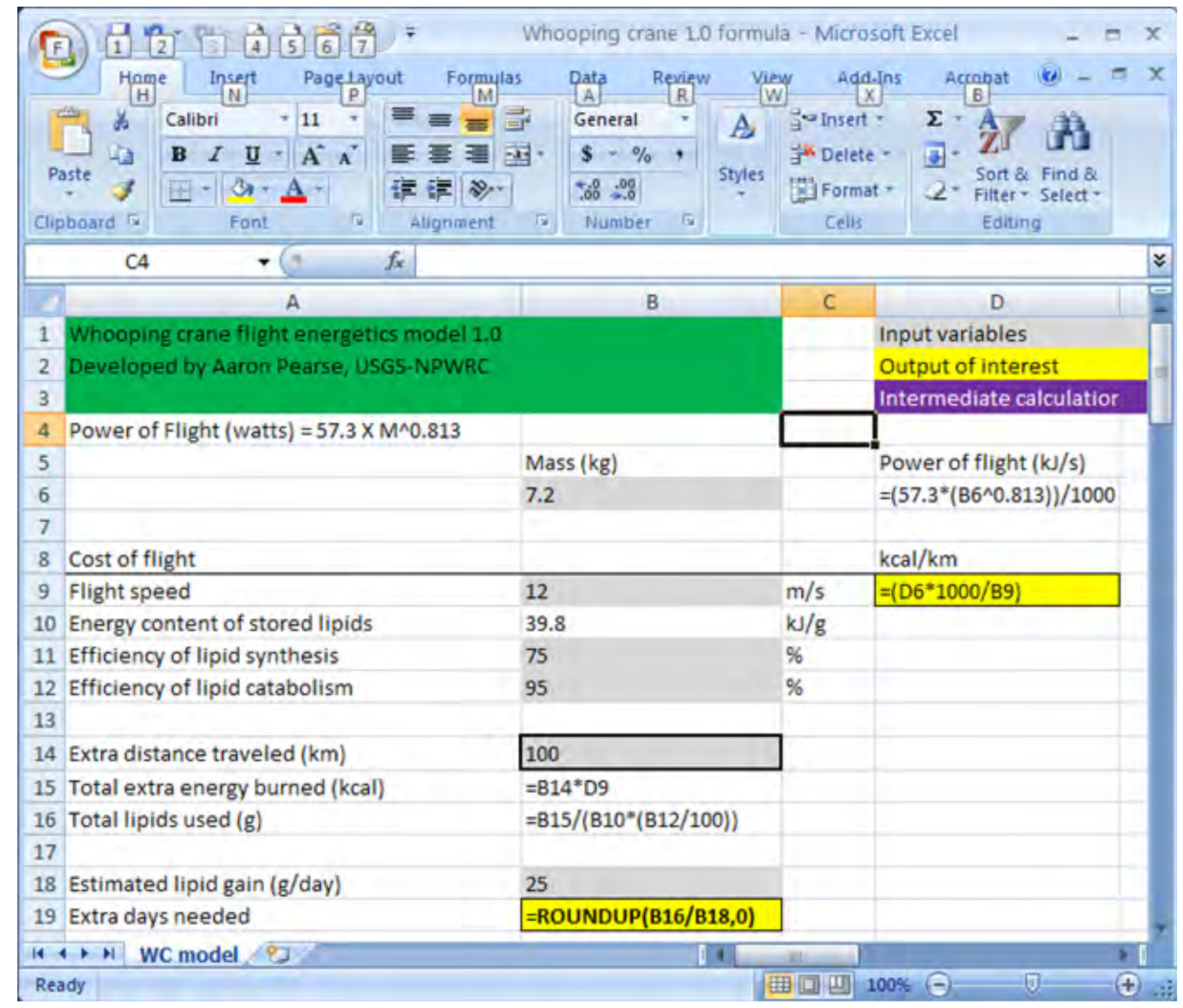




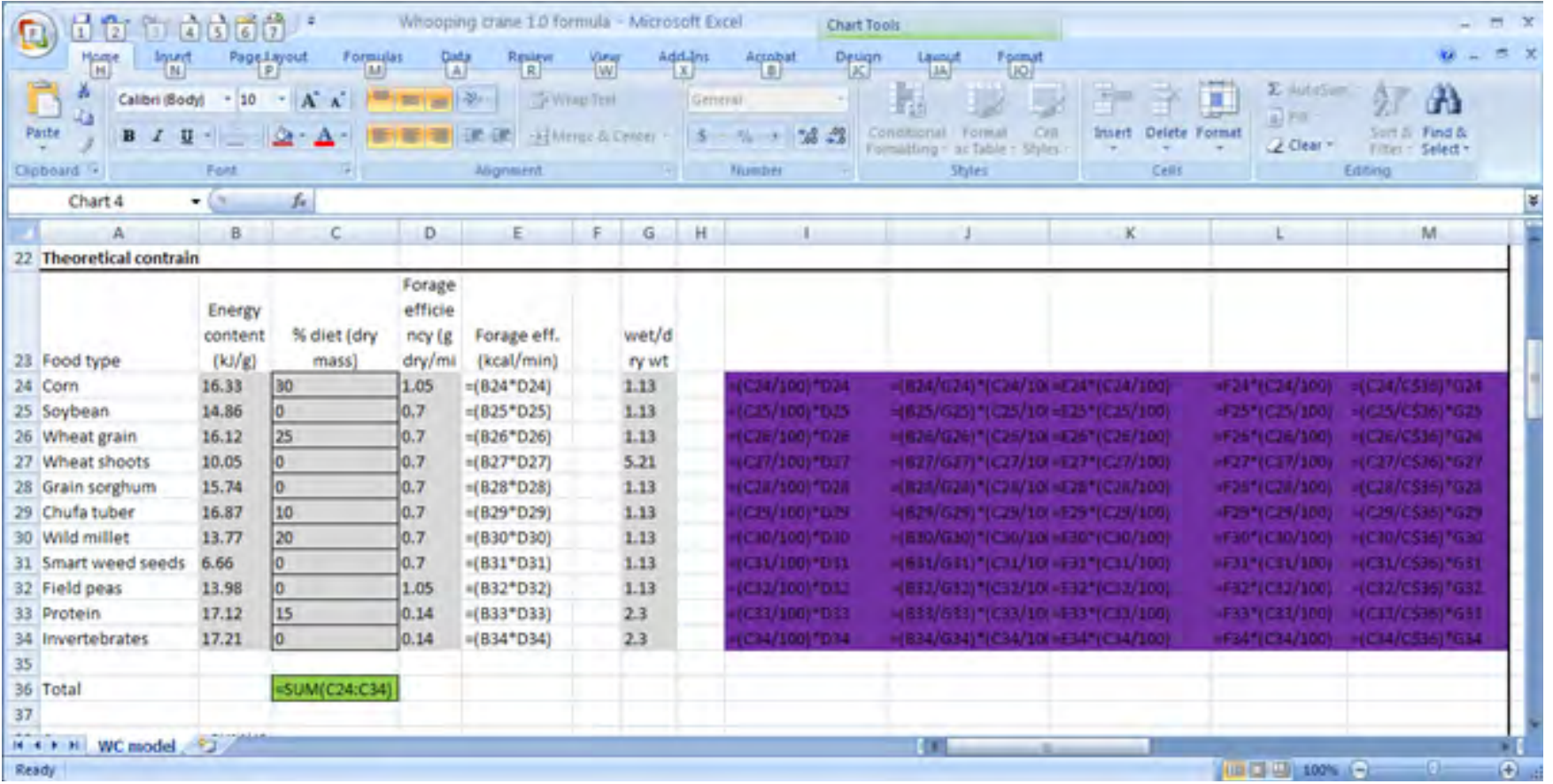

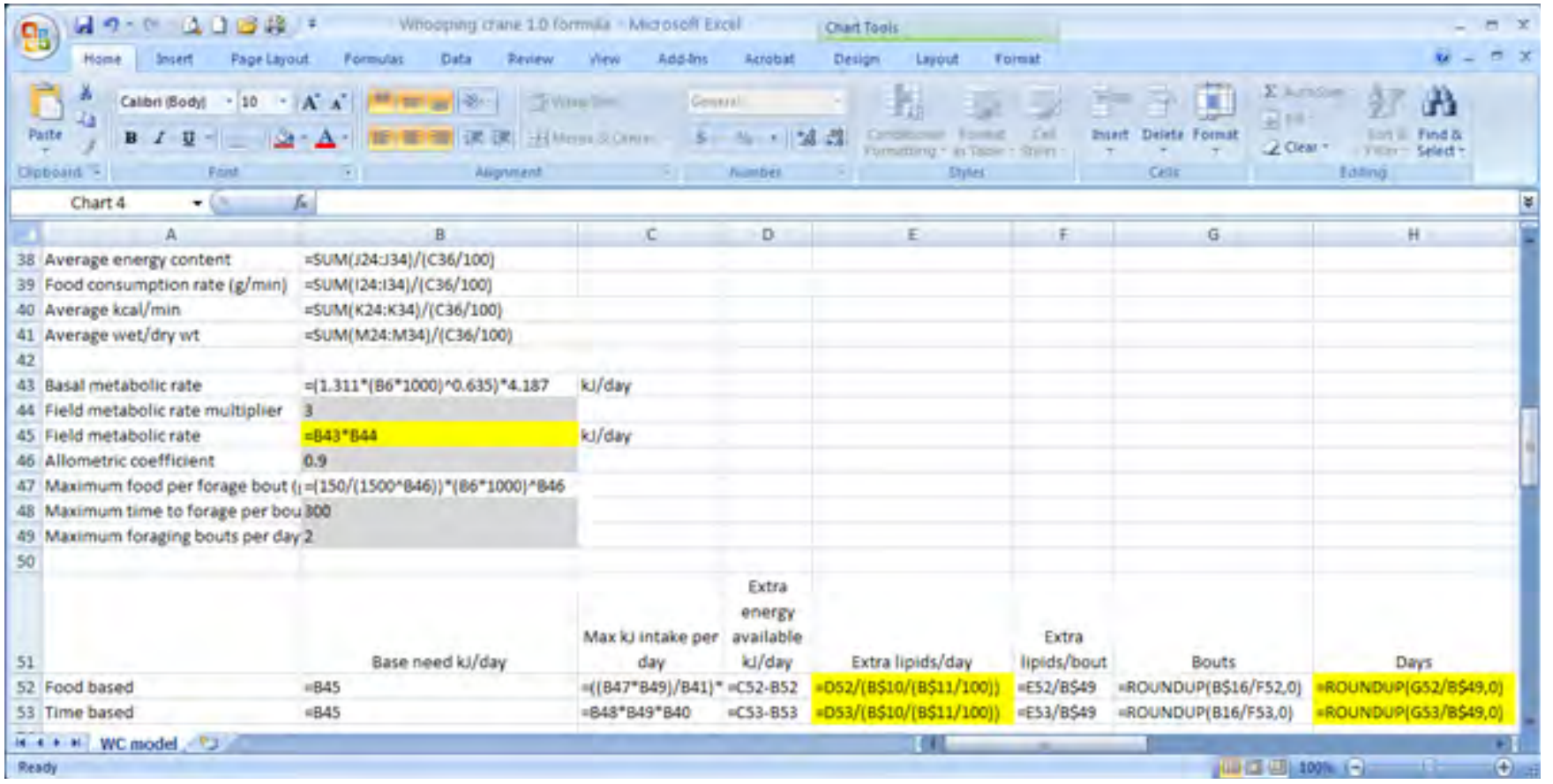


Publishing support provided by:

Rolla Publishing Service Center

For more information concerning this publication, contact:

Director, USGS Northern Prairie Wildlife Research Center

8711 37th Street Southeast

Jamestown, North Dakota 58401

(701) 253-5553

Or visit the Northern Prairie Wildlife Research Center Web site at: http://npwrc.usgs.gov/ 



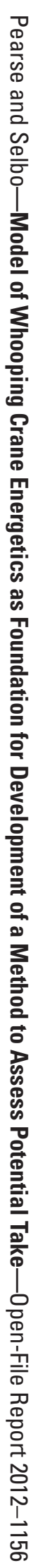

